\title{
Open Source Software, Benefits in the Economy of Bangladesh
}

\author{
Mohammad Jahangir Alam \\ Lecturer \\ Department of Computer Science and Information Technology, \\ Southern University Bangladesh, Goalpaher Circle, Chittagong, Bangladesh.
}

\begin{abstract}
Open source software is very popular now a days. It is popular because its source code is opened to all. Any programmer, software developer can change its source code and develop a new one. It's another option is that any one can use these software or download different tools free of cost from different websites. For these reasons open source software's popularity is increasing day by day in the ICT sector. All kinds of software are available in open source software for using from home to commercial purpose. By using the open source software Bangladesh can be benefited in many ways. Now I am going to focuse on the different benefits of open source software for Bangladesh.
\end{abstract}

\section{Keywords}

Information Technology (IT), Information and communication Technology (ICT), Bangladeh Computer Council (BCC), Bangladesh Association of Software and Information Services (BASIS), Open Source Software(OSS).

\section{INTRODUCTION}

Bangladesh is a developing country. Most of the people are living under the poverty level. Government has to spend a large amount of money to full fill the basic needs of people. So, it is too hard for the government to spend money for others sectors like IT. But, without improvement of IT no country around the world will rich to their economic goal or develop life style of people. So to realize the reality, government has taken many steps to

improve IT sector. Currently, Government of Bangladesh is implementing the project of e-Governance, providing computer from school level to university, Smart class room program in primary school level and using computer most of the government offices are the reflection of the Digital Bangladesh. But it is costly for the government to buy proprietary software to run the new projects and the new computers. So the Government can easily use all kinds of open source software to implement those projects and run the computers and can save large amount of money. Because open source software's source code is available to the general public for using as is or modification from its original design and must allow distribution in source code as well as compiled form. This software typically does not require a license fee ${ }^{[1]}$

\section{ADVANTAGES OF OPEN SOURCE SOFTWARE}

\subsection{Source code is open to all}

The main advantage of open source software is code which is opened to all public for using, modification or update. So, any one can modify the source code without taking permission from any person or any vendor.

2.2 Freedom of choosing vendor No one needs to depend on any vendor for their software. If they do not feel comport with any open source software they can change any vendor any time.

\subsection{Free of cost}

It is almost free of cost. It is not necessary to pay money to any company for buying software or license fees or annual fee or at once. Because, it is the contribution of world wide community.

\subsection{Security}

It is more secure and reliable. Because this is not necessary to depend on any vendor to take the security code. A large amount of developers are globally contributing and distributing the code for security. So, any one can take it very easily. It is also possible to implement own security code as any one wants.

\subsection{Distribution of software}

Any public can distribute the software to any one without permission from others which is not possible in propriety software.

\section{DISADVANTAGES OF OPEN SOURCE SOFTWARE}

3.1 No option to claim for bugs There is no option in open source software to claim to any specific vendor or person for any software bugs. So it is a little bit problem for someone or organization.

\subsection{Continuous development}

There is no guaranty for continuity of development process of open source software. Any one or any community may stop the development or support of any software for any reason. 


\section{COMPARISONS BETWEEN OPEN SOURCE SOFTWARE AND PROPRIETARY SOFTWARE}

Table1. Comparison of OSS and Proprietary software

\begin{tabular}{|c|c|c|}
\hline & $\begin{array}{c}\text { Open } \\
\text { Source } \\
\text { Software } \\
\end{array}$ & $\begin{array}{c}\text { Proprietary } \\
\text { Software }\end{array}$ \\
\hline Cost & $\begin{array}{c}\text { Open source } \\
\text { software is } \\
\text { free. }\end{array}$ & $\begin{array}{l}\text { Have to pay } \\
\text { to the } \\
\text { company or } \\
\text { software } \\
\text { owner. }\end{array}$ \\
\hline $\begin{array}{c}\text { Service and } \\
\text { Support }\end{array}$ & $\begin{array}{c}\text { Relies on } \\
\text { online } \\
\text { community } \\
\text { users and } \\
\text { developers to } \\
\text { deliver } \\
\text { support via } \\
\text { forums and } \\
\text { blogs }\end{array}$ & $\begin{array}{l}\text { Service and } \\
\text { support } \\
\text { provided by } \\
\text { vendor. }\end{array}$ \\
\hline $\begin{array}{l}\text { Ownership } \\
\text { of the } \\
\text { Software }\end{array}$ & $\begin{array}{c}\text { No } \\
\text { ownership, } \\
\text { because } \\
\text { developed by } \\
\text { the } \\
\text { community } \\
\text { around the } \\
\text { world }\end{array}$ & $\begin{array}{c}\text { Organization } \\
\text { or vendor } \\
\text { who created } \\
\text { it. }\end{array}$ \\
\hline $\begin{array}{l}\text { Modification } \\
\text { the source } \\
\text { code }\end{array}$ & $\begin{array}{l}\text { Modification } \\
\text { is possible, } \\
\text { any user can } \\
\text { modify the } \\
\text { source code. }\end{array}$ & $\begin{array}{l}\text { Modification } \\
\text { can not do by } \\
\text { the user or } \\
\text { client except } \\
\text { creator or } \\
\text { vendor. }\end{array}$ \\
\hline Security & Not so strong & $\begin{array}{c}\text { More secure, } \\
\text { Because it is } \\
\text { developed by } \\
\text { the vendor } \\
\text { with their } \\
\text { expert team } \\
\text { members } \\
\text { who test and } \\
\text { update the } \\
\text { code regular } \\
\text { basis. }\end{array}$ \\
\hline Liabilities & $\begin{array}{l}\text { No specific } \\
\text { one }\end{array}$ & $\begin{array}{c}\begin{array}{c}\text { For any kind } \\
\text { of program } \\
\text { bugs, }\end{array} \\
\text { vendors take } \\
\text { the liability. }\end{array}$ \\
\hline Redistribute & Possible & Not allowed \\
\hline
\end{tabular}

\section{AVAILABLE OPEN SOURCE}

\section{SOFTWARE}

Now a days, our daily life can not be imagined without a computer. From home to office we use computer for various purposes. For this reason, we have to use different types of software for different jobs. So, it is true and happy news that all types of software are now available in open source software. Such as, very popular operating system is LINUX, Internet browser is Mozilla Firefox, web server is Apache Tomcat, open-source office productivity software suite like OpenOffice etc. Some Open Source Software's are:
Table2. Open Source Software

\begin{tabular}{|c|}
\hline Finance \\
\hline Bitcoin(www.bitcoin.org), vtiger CRM (www.vtiger.com) \\
\hline Integrated Library System \\
\hline Evergreen(evergreen-ils.org) \\
\hline Computer simulation \\
\hline Blender(www.blender.org) \\
\hline Geographic Information Systems \\
\hline $\begin{array}{l}\text { Chameleon (http://chameleon.maptools.org), } \\
\text { FTools (http://fwtools.maptools.org) }\end{array}$ \\
\hline Microscope image processing \\
\hline $\begin{array}{l}\text { CellProfiler (http://www.cellprofiler.org), } \\
\text { ImageJ(http://rsb.info.nih.gov/ij) }\end{array}$ \\
\hline Grid Computing \\
\hline P-GRADE Portal(http://portal.p-grade.hu) \\
\hline Artificial intelligence \\
\hline $\begin{array}{l}\text { OpenCog(opencog.org), } \\
\text { OpenCV(opencv.willowgarage.com/wiki) }\end{array}$ \\
\hline ROS (www.ros.org) \\
\hline Planning \\
\hline TREX (http://thaiopensource.com/trex) \\
\hline Database management systems \\
\hline MySQL(http://www.mysql.com) \\
\hline Network and security monitoring \\
\hline Admon(http://admon.org/),CFEngine (www.cfengine.com) \\
\hline Firewall \\
\hline $\begin{array}{l}\text { Iptables(www.netfilter.org), } \\
\text { IPFilter(http://coombs.anu.edu.au/ avalon })\end{array}$ \\
\hline Data loss prevention \\
\hline MyDLP(www.mydlp.org) \\
\hline Debuggers (for testing and trouble-shooting) \\
\hline $\begin{array}{l}\text { Xnee(http://www.sandklef.com/xnee), } \\
\text { Memtest86(www.memtest86.com) }\end{array}$ \\
\hline Code generators \\
\hline $\begin{array}{l}\text { openSceneGraph } \\
\text { (http://www.openscenegraph.org), OpenSCDP } \\
\text { (http://www.openscdp.org) }\end{array}$ \\
\hline Bug trackers \\
\hline $\begin{array}{l}\text { Bugzilla(www.bugzilla.org) } \text {, Mantis Bug } \\
\text { Tracker(www.mantisbt.org) }\end{array}$ \\
\hline Programming language support \\
\hline PHP(www.php.net), Ruby(ruby-lang.org) \\
\hline Operating systems \\
\hline Linux(http://www.linux.org) \\
\hline Video editing \\
\hline $\begin{array}{l}\text { DScaler (http://deinterlace.sourceforge.net), } \\
\text { OpenShot Video Editor(openshot.org) }\end{array}$ \\
\hline 2D animation \\
\hline KTooN(http://www.ktoon.net/) \\
\hline 3D animation \\
\hline $\begin{array}{l}\text { OpenFX(http://www.openfx.org), } \\
\text { Seamless3d(http://www.seamless3d.com) }\end{array}$ \\
\hline Image viewers \\
\hline $\begin{array}{l}\text { gThumb(live.gnome.org/gthumb), imgSeek ( } \\
\text { http://www.imgseek.net) }\end{array}$ \\
\hline Geography \\
\hline KGeography(http://kgeography.berlios.de) \\
\hline File managers \\
\hline Dolphin(dolphin.kde.org) \\
\hline Networking and Internet \\
\hline Advertising \\
\hline Limesurvey(www.limesurvey.org),OpenX(www.openx.org) \\
\hline E-mail \\
\hline
\end{tabular}




\begin{tabular}{|l|}
\hline $\begin{array}{l}\text { Agorum core(http://www.agorum.com),Open- } \\
\text { Xchange(open-xchange.com) }\end{array}$ \\
\hline Instant messaging \\
\hline BitlBee(www.bitlbee.org),Bombusmod(bombus-im.org) \\
\hline Communication-related \\
\hline $\begin{array}{l}\text { Asterisk(www.asterisk.org),sipXecs (Enterprise } \\
\text { Communicati ons Server)( } \text { http://www.sipfoundry.org) } \\
\text { OpenVPN(http://openvpn.net/index.php/open- } \\
\text { source.html),Synergy(http://synergy-foss.org) }\end{array}$ \\
\hline Remote access and management \\
\hline $\begin{array}{l}\text { OpenVPN(http://openvpn.net/index.php/open- } \\
\text { source.html),Synergy(http://synergy-foss.org) }\end{array}$ \\
\hline Web browsers \\
\hline $\begin{array}{l}\text { Mozilla Firefox(http://www.mozilla.org/en- } \\
\text { US/firefox),Midori(www.twotoasts.de) }\end{array}$ \\
\hline Web-related \\
\hline $\begin{array}{l}\text { Apache } \\
\text { Cocoon(http://cocoon.apache.org),Apache(httpd.apache.org) }\end{array}$ \\
\hline Portal Server \\
\hline Oxwall(oxwall.org),Liferay(http://www.liferay.com) \\
\hline Middleware \\
\hline $\begin{array}{l}\text { Apache } \\
\text { Axis2(http://axis.apache.org/),Glassfish(glassfish.java.net) }\end{array}$ \\
\hline Educational \\
\hline Educational suites \\
\hline DoceboLMS(www.docebo.org),eFront(efrontlearning.net) \\
\hline Learning support \\
\hline $\begin{array}{l}\text { SchoolForge(http://www.schoolforge.net),CoFFEE(CoFFEE- } \\
\text { soft.org) }\end{array}$ \\
\hline Language \\
\hline Kverbos(http://edu.kde.org/kverbos) \\
\hline
\end{tabular}

\section{IT SECTOR IN BANGLADESH}

Use of computers in Bangladesh as a research and data manipulation tool dates back more than 40 years. The first computer in Bangladesh (erstwhile East Pakistan) was installed at the ATOMIC ENERGY CENTRE, Dhaka of Pakistan Atomic Energy Commission in 1964. It was an IBM Mainframe Computer of 1620 series. The main use of the machine was resolving complicated mathematical calculations in different research work ${ }^{[3]}$. Today computers are widely used in offices, businesses, educational institutions, at home and in the filed. Most of the banks providing online transaction facilities and they are using different types of software from different vendors. For using different types of software they are paying large amount to the software company. In one of the most progressive policy orientation towards ICT of any nation on the earth today, Bangladesh allows $100 \%$ duty-and-tax-free import of all computer hardware and software which expedites the use of computers and the growth of the ICT industry.

The ICT industry in Bangladesh is represented by Bangladeh Computer Council (BCC). BCC is a statutory body under the Ministry of Information \& Communication Technology, Government of Bangladesh for encouraging and providing support for ICT related activities in Bangladesh. It is established by Act No IX of 1990 passed through the Parliament ${ }^{[2]}$. It is constituted with 7 members namely, Bangladesh Association of Software and Information Services (BASIS), Internet Service Providers Association Bangladesh (ISPAB), Bangladesh Computer Samity(BCS), Bangladesh Computer Society(BCS), Cyber Café Owners Association of Bangladesh(CCOAB), Cable Operators Association of Bangladesh(COAB), Association of Mobile Telecom Operators in Bangladesh (AMTOB).
Bangladesh Association of Software and Information Services (BASIS) is the national trade body for Software \& IT Enabled Service industry of Bangladesh. Established in 1997, the association has been working with a vision of developing vibrant software \& IT service industry in the country. BASIS started its journey with only 17 charter members. Today the membership stands at more than 450. Members of BASIS account for the lion share of the total software \& IT services revenue of the country ${ }^{[4]}$. Bangladesh government has been taken many steps to establish a Hi-Tech Park with the vision to establish a world class business environment for targeted high growth IT industrial sector and to compete in the IT business, to develop indigenous technological capability for the development of the local industries, to enter into foreign markets by exporting state of the art technology products and Infrastructure to facilitate hassle-free industrial operation with necessary support ${ }^{[5]}$. Bangladesh is also connected with Submarine Cable connection to Global Information Superhighway(SEA-ME-WE-4) which has unfolded a new era of IT sector.

\section{HOW BANGLADESH CAN BE BEFITTED?}

In Bangladesh, currently the government is running eGovernance to fulfill the dream of DigitalBangladesh (http://www.digitalbangladesh.gov.bd/bangla/index.php). The national ICT Task Force headed by the Honorable Prime Minister herself has given more importance on recognizing challenges to implement nation-wide e-Governance. For this reason, government has started a pilot projects in various sectors of the government called the Support to ICT Task Force. It is being implemented under the Ministry of Planning. Also, the Government of Bangladesh is getting considerable foreign co-operation in terms of financial assistance and technical collaboration for realization of eGovernance at a national scale. The initially implemented national web portal address of Bangladesh is (http://www.bangladesh.gov.bd/). For implementing the projects and running computer in various projects government is using different types of proprietary software and spending large amount of money to buy proprietary software for those projects. For this purpose the government can use the open source software for implementing the projects and the government can be benefited many ways which are discussed below:

\subsection{Financially}

A Large amount of money of government can be saved if the government uses open source software in different IT sectors of government offices and others sectors , Because government is providing computer to all educational institute from school to university level and they are using proprietary software. For this reason government is to expend a large amount of many for buying proprietary software to run the computers. Another one is government paying significant amount of money to the different vendors for buying different types of software to implement e-Governance project. So, the Government can use open source software for implanting projects to minimize cost of the projects.

\subsection{Skilled people}

Government is trying to involve the people of Bangladesh with the project of e-Governance. It can be easy for the government if they use the open source software in their projects all aspect so that people get the opportunity to see and modify the source code of the software and get the option 
of real practical life. As a result government can get some IT skilled people who are valuable asset for the country.

\subsection{Computer with minimum cost}

Still now the price of the Computer is out of the range of the Bangladeshi people. It's price is not only so high but also for buying integrated proprietary software. The price of computer can be almost half if the government is impose the rule to use open source software with each machine. As a result maxim number of people will get the opportunity to buy and use computer.

\subsection{Decreased the un-employment}

Unemployment problem is the big issue for any developing country. Bangladesh also is not out this problem. If the government runs all the projects using open source software then government can recruit many people to develop the projects. As a result a large number of educated people will get the opportunity for doing the job with modern technology like IT. For this reason unemployment ratio can be decreased day by day which will bring very good result for the country.

\subsection{Government can expend the money in other sectors}

Government has to expend huge amount of money in different development sectors of the country. But it is too difficult for any developing country like Bangladesh to invest any project. For this reason, government has to depend on many developed countries, World Bank, IMF or European Union for running any projects. Such as government implementing the eGovernance project with the help of World Bank or others developed countries. So if the government implement the full project using open source software then government needs not necessary to depend on world Bank or others for their investments and the government can easily invest the amount to others development project.

\subsection{Exporting manpower to foreign country}

If the people get the opportunity to involve government running open source software projects then they became skilled person because they will get the real experience in their practical life of open source software. If they go abroad for job purpose they can earn handsome money and will contribute to develop the country.

\section{CONCLUSION}

From the discussion I can say that from personal to commercial purpose we can use Open source software. For the advantages of free of cost save a large amount of money .As we live in third world country, most of the people of our country live in poor condition. If we use open source software in our home, office, industry, school, college, and university it can save a large amount of money which we are spending for using proprietary software. Although it is free of cost, its security systems are very powerful. We can develop or design different software as required for our office or home use by the help of open source software. Our software industries also will be benefited if they can take the advantages of the open source software. Our economic condition will be improved if we use Open Source software in all sectors. It is the great blessing for Bangladesh IT sector to keep peace with the $21^{\text {st }}$ century which will be emerged for Bangladesh as a Digital Century.

REFERENCES [1] http://www.opensource.org

[2] http://www.banglapedia.org/httpdocs/HT/

\section{0328. HTM}

[3] http://www.bcc.net.bd/index.html

[4] http://www.basis.org.bd/index.php/about

[5]http://www.htpbd.org.bd/index.php/mission -and-objective

[6] http://www.linux.org/info

[7] http://www.cyberciti.biz/tips/open-source-projectmanagement-software.html

[8] http://bdosn.org/why_open_source.php

[9] ww.banglait.org/ICTBANGLADESH.ppt

[10]http://www.ubuntu.com/project/about-ubuntu/ourphilosophy

[11] Steven Weber, October 31, 2005, The Success of Open Source.

[12]_Karl Fogel, October 14, 2005, Producing Open Source Software: How to Run a Successful Free Software Project.

[13] Susan Walton, January 1999, Open sources: Voices from the Open Source Revolution.

[14] Glyn Moody,July 15, 2002, Rebel Code: Linux And The Open Source Revolution.

[15] Joseph Feller, Brian Fitzgerald, Scott A. Hissam, and Karim R. Lakhani, 2005, Perspectives on Free and Open Source Software.

[16] Sanjiva Weerawarana, jivaka Weeratunga, January, 2004, Open Source in Developing Countries.

[17] Michael W. Godfrey and Qiang Tu, Evolution in Open Source Software: A Case Study.

[18]The Parliamentary Office of Science and Technology, London, June 2005, Open Source Software.

[19] David M Nichols and Michael B Twidale, December 2002, Usability and Open Source Software. 